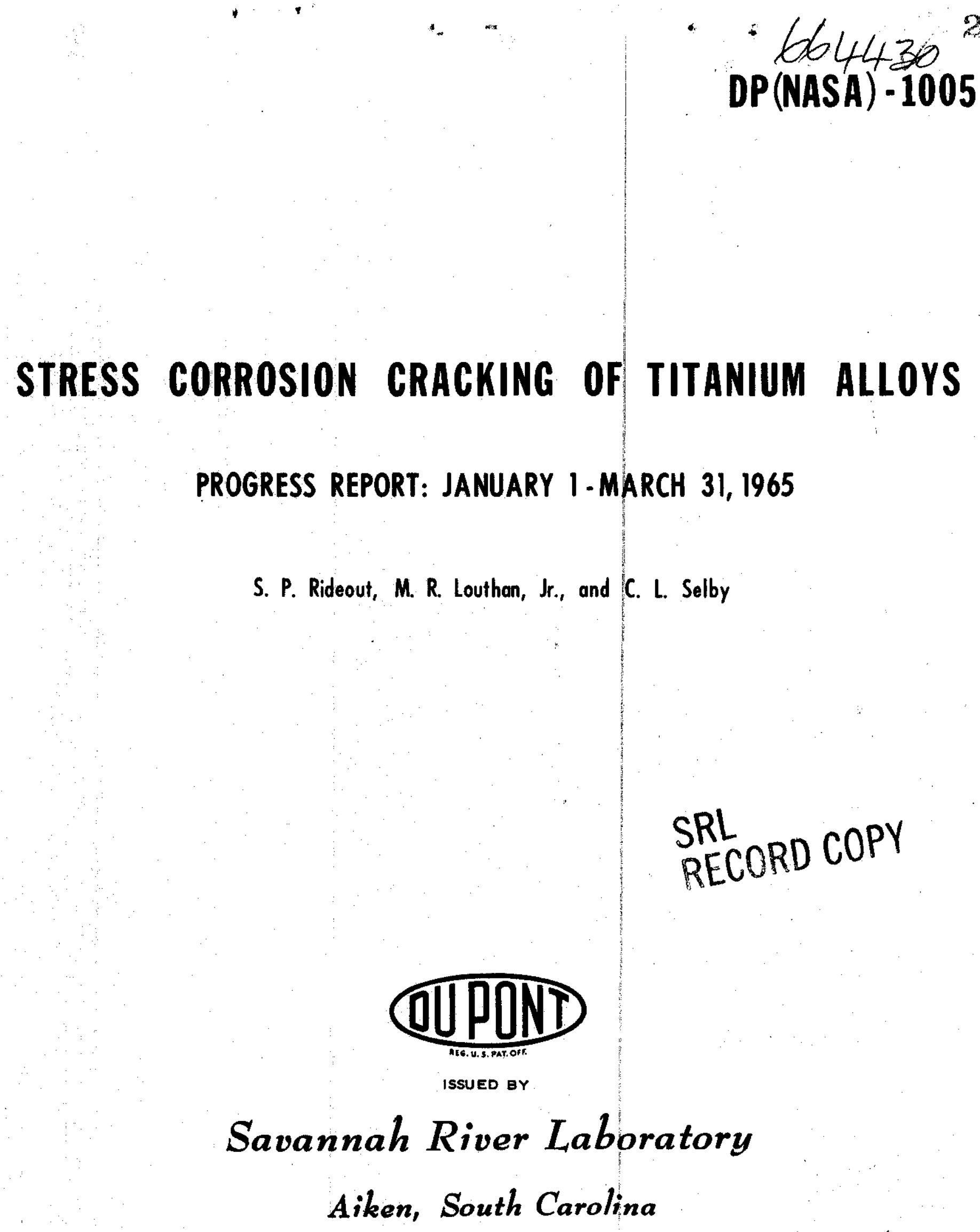




\title{
STRESS CORROSION CRACKING OF TITANIUM ALLOYS
}

PROGRESS REPORT: JANUARY 1 - MARCH 3I, 1965

\author{
by \\ Sheldon P. Rideout \\ McIntyre R. Louthan, Jr. \\ Clifford I. Selby \\ Approved by \\ P. H. Permar, Research Manager \\ Nuclear Materials Division \\ September 1965
}

\section{Prepared for}

National Aeronautics and Space Administration Work performed under NASA Purchase order No. R-124, Issued to the United States Atomlc Energy Commission

\author{
E. I. DU PONT DE NEMOURS \& COMPANY \\ SAVANNAH RIVER LABORATORY \\ AIKEN, SOUTH CAROLINA \\ CONTRACT AT(07.2).1 WITH THE \\ UNITED STATES ATOMIC ENERGY COMMISSION
}




\begin{abstract}
This is the fourth quarterly progress report of research directed toward determination of the mechanism of hot-salt cracking of Ti-8Al-1Mo-1V.

Radiographic evidence showed that ${ }^{3} \mathrm{H}$ and ${ }^{36} \mathrm{Cl}$ are retained on sample surfaces, probably as $\mathrm{HCl}$, after exposure to aqueous salt solutions. Adsorption of $\mathrm{HCl}$ appears to be a key factor in causing susceptibility to hot-salt cracking. Exposure to anhydrous $\mathrm{HCl}$ gas at $650^{\circ} \mathrm{F}$ caused abrupt mechanical rupture in stressed samples. Exposure to liquid $\mathrm{NaOH}$ at $650^{\circ} \mathrm{F}$ caused corrosion and preferential attack of aluminum, but no cracking. Aluminum is also preferentially attacked by NaCl during hotsalt cracking. Prior treatments with $\mathrm{NaOH}$, which preferentially remove the aluminum from the sample surfaces, delayed the inception of stress cracking during subsequent exposures to solid $\mathrm{NaCl}$ or $\mathrm{HCl}$ gas. Results are interpreted to show that hot-salt cracking and HCl-gas cracking are similar and occur by either hydrogen embrittlement or by localized, stress-accelerated corrosion.
\end{abstract}




\section{CONTENTS}

Page

List of flgures . . . . . . . . . . . . . . . . 4 Introduction . . . . . . . . . . . . . . . . 5 Summary . . . . . . . . . . . . . . . . . 5 Review of Previous Work ................. 5 Summary of Fourth Quarter . . . . . . . . . . . 6 Discussion .................... 8

Experimental Procedure . . . . . . . . . . . . 8 Experimental Results . . . . . . . . . . . . . 8 Cracking in $\mathrm{HCl}$ Gas . . . . . . . . . . . . . . 8 Role of Hydrogen in Hot-Salt Cracking . . . . . . . . . 13 Role of $\mathrm{NaOH}$ and Preferential Attack of Al in Cracking . . 15 Effects of Corrosion, Stress, and Temperature on Cracking . 19 Cyclic Tests . . . . . . . . . . . . . . 20 Effect of Heat Treatment on Cracking . . . . . . . . . . 21 Effect of Oxygen . . . . . . . . . . . . . . 21 Effect of Various Halogen Ions on Cracking . . . . . . . 22 References . . . . . . . . . . . . . . . . . 23 


\section{LIST OF FIGURES}

Figure

Page

1 Typical Crack Pattern on Surface of

Stressed T1-8Al-1Mo-IV Alloy Exposed in Anhydrous $\mathrm{HCl}$ Gas at $650^{\circ} \mathrm{F}$ for $6 \frac{1}{2}$ Hours. . . . . 11

2 Fractographic Comparison of Cracks Developed in Ti-8Al-1Mo-IV Alloy Exposed at $650^{\circ} \mathrm{F}$ to Anhydrous $\mathrm{HCl}$ and to $\mathrm{NaCl} . . . . . . . . . . .1212$

3 Distribution of ${ }^{3} \mathrm{H}$ on Salt-Corroded T1-8Al-IMo-IV Alloy $(5 \mathrm{X})$. . . . . . . . . . 14

4 Distribution of ${ }^{3} \mathrm{H}$ on Salt-Corroded Ti-8Al-1Mo-IV

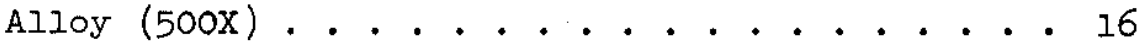

5 Microscopic Appearance of Surface of Stressed Ti-8Al-1Mo-IV Alloy Exposed to NaOH at $650^{\circ} \mathrm{F}$ for 10 Days, Then Exposed to NaCl at $650^{\circ} \mathrm{F}$ for 7 Days. 17

6 Unidentified Body-Centered Cubic Phase Extracted from T1-8Al-1Mo-1V Alloy After Attack by $\mathrm{NaCl}$. . 19

7 Effect of Successive NaCl Exposures on Nucleation and Propagation of Hot-Salt Cracks....... 21

8 Appearance of Stressed Ti-8Al-1Mo-1V Alloy Exposed to $\mathrm{NaF}$ for 14 Days at $650^{\circ} \mathrm{F}$. . . . . . . . . 22 


\section{STRESS CORROSION CRACKING OF TITANIUM ALLOYS PROGRESS REPORT: JANUARY 1 - MARCH 31, 1965}

\section{INTRODUCTION}

The Savannah River Laboratory is engaged in a program of NASAsponsored research to develop fundamental knowledge about the mechanism of hot-salt stress corrosion cracking of titanlum alioys. Study of the behavior of Ti-8Al-1Mo-IV alloy is being emphasized because it is a prime candidate as a structural material for the proposed supersonic transport (SST). This alloy is known to be susceptible to hot-salt cracking in laboratory tests under conditions that may occur during SST operation; $1 . e .$, skin temperature in the range of $550-650^{\circ} \mathrm{F}$ with sea salt contamination acquired during transoceanic operations.

Microautoradiography of samples exposed to salt contalning radiotracers ${ }^{36} \mathrm{Cl},{ }^{22} \mathrm{Na}$, and ${ }^{3} \mathrm{H}$ is being used to investigate the role of these elements in the stress corrosion cracking phenomenon. Electron and optical microscopy techniques are being used to study crack morphology and the effects of alloy structure on cracking.

This is the fourth quarterly progress report; previous reports in the series have been DP(NASA)-917, 941, and 96I. TIming on the issue of these reports is such that interpretations of results are tentative and may change as additional information is developed.

\section{SUMMARY}

\section{REVIEW OF PREVIOUS WORK}

Results reported previously $(1,2,3)$ on cracking of stressed Ti-8AlIMo-IV at $650^{\circ} \mathrm{F}$ are reviewed below for convenience.

- Cracking occurred during exposures to various chloride salts (deposited from saturated aqueous solutions) including natural sea salt, $\mathrm{NaCl}, \mathrm{KCl}, \mathrm{MgCl}_{2}$, and $\mathrm{CaCl}_{2}$. For a given exposure time, cracking caused by $\mathrm{MgCl}_{2}$ and $\mathrm{CaCl}_{2}$ was the least severe, indicating an effect of cation species possibly related to chemical activity of their hydroxides.

- Cracking occurred during exposures to $\mathrm{NaI}$ and $\mathrm{NaBr}$, demonstrating that the chloride ion is not unique in causing cracking.

- Cracks formed at points where salt crystals were in intimate contact with the surface, and propagated along alpha grain boundaries and alpha-beta phase boundaries. Crack propagation 
was faster in samples cooled very slowly from the annealing temperatures $\left(1450^{\circ} \mathrm{F}\right.$ ) than in samples cooled very rapldiy.

- Comparison of samples having metallographically polished surfaces with samples having thicker oxide films showed that oxide films delayed cracking, indicating that reactants must either diffuse through or dissolve the oxide films.

- Analyses of salt-metal corrosion products showed a higher ratio of aluminum to titanium than in the base metal, indicating that preferential attack of aluminum may be involved in the stress corrosion cracking phenomenon.

- Microautoradiography of samples exposed to salt containing radiotracers ${ }^{22} \mathrm{Na}$ and ${ }^{38} \mathrm{Cl}$ showed that chloride ions were uniformly adsorbed and retalned on the surface initially wetted by the saturated aqueous solution used to apply the salt deposit. Sodium was retained only at points where the salt crystals that formed on drying adhered to the metal surface.

- Tests demonstrated that $\mathrm{HCl}$ gas is given off during initial heating of salt with and without metal present, raising the possibility that the $\mathrm{HCl}$, and/or concelvably the resultant hydroxides in the salt deposit, may be involved in inltiating stress corrosion.

- Samples w1thout salt deposits cracked to complete rupture in anhydrous HCl gas at $650^{\circ} \mathrm{F}$ and one atmosphere pressure.

- Observations of the Ti-8Al-1Mo-IV alloy substructure indicated that the alpha matrix had a relatively low stacking fault energy, suggesting a possible susceptibility to transgranular stress corrosion cracking.

- A hydride phase was observed in folls which were contaminated with hydrogen during the thinning operations. The hydride was concentrated along alpha-alpha and alpha-beta boundaries, suggesting that the affinity for hydrogen was higher in these regions.

\section{SUMMARY OF FOURTH QUARTER}

Tests performed during this period provide evidence that hydrogen embrittlement may play a vital role in stress corrosion cracking of titanium alloys. The evidence is particularly strong in cases of cracking in $\mathrm{HCl}$ gas. 
Observations to date on cracking caused by halogen salt deposits can be interpreted to support either of the hypotheses that cracking occurs (I) as a result of hydrogen embrittlement, or (2) as a result of localized, stress-accelerated corrosion. Some corrosion by salt or $\mathrm{HCl}$ gas seems to be necessary for cracking to occur, but the primary role of corrosion could be to produce hydrogen. The corrosion is electrochemical in nature, and the anodic half-cell reaction, which is oxidation of the metal, must be accompanied by a cathodic reaction, which may be reduction of either hydrogen ions or oxygen. Continuing studies using radiotracer ${ }^{3} \mathrm{H}$ (tritium) will define the role of hydrogen.

Preferential attack of aluminum (and possibly ivanadium) in the alloy appears to be a key factor in the cracking phenomenon. Experimental results obtained during this period are summarized below.

- Cracking in $\mathrm{HCl}$ gas at $650^{\circ} \mathrm{F}$ appears to occur by abrupt mechanical rupture of metal embrittled by corrosion-produced hydrogen. Polished samples without salt deposits cracked to complete rupture within $6-1 / 2$ hours. Thick oxide films delayed but did not prevent cracking.

- On a salt-coated sample exposed at $650^{\circ} \mathrm{F}$, radiotracer ${ }^{3} \mathrm{H}$ (tritium) was shown by autoradiography to be retained fairly uniformly in the area wetted initially by aqueous salt solution. The hydrogen is believed to have been retained initially either as $\mathrm{HCl}$ molecules or $\mathrm{H}^{+}$ions dispersed with $\mathrm{Cl}^{-}$ions in the surface film to maintain charge balance. Some moisture may also be adsorbed. The presence of moisture and adsorbed hydrogen and chloride ions appears to be a key factor in causing susceptibility to hot-salt cracking.

- Exposures to $\mathrm{NaOH}$ alone caused pitting and preferential attack of the alloying elements in the metal, but no cracking. Deposits of $\mathrm{NaCl}$ on areas previously exposed to $\mathrm{NaOH}$ at $650^{\circ} \mathrm{F}$ did not cause cracking in experiments run to date.

- Corrosion started within one hour on polished, unstressed samples exposed to $\mathrm{NaCl}$ at various temperatures between 200 and $650^{\circ} \mathrm{F}$. No change in the nature of attack with temperature was evident, although the extent of corrosion increased with increasing temperature and time of exposure.

- An unidentified phase was extracted from salt-corroded areas and from the fracture surfaces of cracks produced by $\mathrm{NaCl}$ and $\mathrm{HCl}$ exposure; however, only traces of the phase were present on the HCl-exposed samples. The possible role of this phase in hot-salt cracking is being investigated. 
- Additional studies of the role of the halide ion confirmed the previous results that cracking could be produced by $\mathrm{NaCl}$, NaI, and $\mathrm{NaBr}$, and showed that NaF did not cause cracking.

- X-ray diffraction studies revealed no varlations in alloy structure with cooling rate from $1450^{\circ} \mathrm{F}$ that could be related to the previously reported observation of a variation in cracking susceptibility.

- Repeated exposures to $\mathrm{NaCl}$ at $650^{\circ} \mathrm{F}$ followed by rinsing in $\mathrm{H}_{2} \mathrm{O}$ and recoating with $\mathrm{NaCl}$ revealed that the cracks formed in one cycle did not propagate during subsequent cycles, although additional cracks did nucleate. This result, coupled with the results of similar tests at Boelng, (B) suggests that hot-salt attack may not be a serious problem because of the cyclic nature of the exposure during operation of the SST.

\section{DISCUSSION}

\section{EXPERIMENTAL PROCEDURE}

Test procedures used in this period were essentially the same as reported previously. $(1,2,3)$ Except where noted in the discussion, all samples were duplex-annealed T1-8AI-IMo-IV with metallographically polished surfaces and stressed to the yield point at $650^{\circ} \mathrm{F}$. In most cases, salt deposits were applied by evaporating several drops of saturated aqueous solution on the stressed samples. Samples exposed in $\mathrm{HCl}$ gas were sealed in glass capsules that had been evacuated, flushed first with argon, then with $\mathrm{HCl}$ gas, and fllled with anhydrous $\mathrm{HCl}$ gas to give one atmosphere of pressure at $650^{\circ} \mathrm{F}$.

\section{EXPERIMENTAL RESULTS}

\section{Cracking in $\mathrm{HCl}$ Gas}

Evidence that $\mathrm{HCl}$ gas was given off when sea salt, $\mathrm{NaCl}$, and salt-metal mixtures were heated $(1,2,3)$ prompted tests to determine if $\mathrm{HCl}$ gas alone causes cracking. As reported previously (3), selfstressed samples of the type used by Braskl and Heimerl ${ }^{(4)}$ cracked to complete rupture within 24 hours at $650^{\circ} \mathrm{F}$, but failures occurred near spot welds at the ends where the metal had also been cold-worked by bending.

During this period, tests in HCl gas were continued using fourpoint loaded strips free of cold-worked areas and spot welds. Because previous tests with $\mathrm{NaCl}$ deposits had shown that thick oxide films delayed initiation of cracking, samples with polished surfaces and anodically oxidized surfaces were exposed in $\mathrm{HCl}$ gas at $650^{\circ} \mathrm{F}$. 
These tests provided evidence that cracking in HCl probably occurred by mechanical rupture of metal embrittled by corrosionproduced hydrogen. Polished samples (no salt deposit) were completely ruptured within $6-1 / 2$ hours exposure. Cracking appeared to occur abruptly, similar to the delayed-fallure phenomenon associated with hydrogen embrittlement. Some secondary cracks occurred in a chevron pattern at an angle of about $75^{\circ}$ to the main crack, which was perpendicular to the direction of tensile stress (Figure 1). Electron micrographs of the crack faces showed evidence of cleavage fracture in some areas (Figure 2a). Although there were traces of a corrosionproduced body-centered cubic phase, the failure appeared to have occurred by mechanical rupture.

As in the case of $\mathrm{NaCl}$ cracking, thick oxide fllms delayed initiation of cracking. The sample with the thickest fllm falled after 72 hours exposure. These results are described in detall below.

Four samples were encapsulated separately; two had polished surfaces, one was anodized in saturated $\mathrm{NaNH}_{4} \mathrm{HPO}_{4}$ to produce a goldcolored oxide about $300 \mathrm{~A}$ thick, and one was anodized to a purplecolored oxlde about $600 \AA$ thick. The sample with the purple oxide and one of the pollshed samples were exposed at $650^{\circ} \mathrm{F}$ for 20 hours, then removed from the fumace and air cooled. The polished specimen had fractured but the oxidized specimen appeared undamaged.

The specimen with the thick purple oxide was returned to the furnace along with the other polished specimen and the specimen with a gold oxide. During this test, the encapsulated samples were inspected periodically. The polished sample fractured after $6-1 / 2$ hours exposure at $650^{\circ} \mathrm{F}$ and was removed from the fumace. The anodized samples both fractured after a continuous exposure of 2 days. Thus the total hightemperature exposure of the specimen with the purple oxide was almost 3 days.

During the 2-day exposure the purple specimen gradually changed to a gold color. The change occurred in streaks; some purple color remained at the ends of the specimen at the end of the exposure. After cooling to room temperature, the specimen again turned purple but had a crystalline appearance. When the glass capsule was broken and laboratory air was admitted to the specimen, the specimen surface developed a gray-white nonadherent coating after a short time. No color changes occurred on the other specimen.

The product formed on the heavily anodized sample was found to be amorphous by electron diffraction, and it melted at a relatively low temperature in the electron beam. Spectrographic analysis showed that the material was very rich in titanium and molybdenum, but the aluminum content was quite low. This result, together with previously reported 
evidence that aluminum is enriched in the oxide on Ti-8Al-1Mo-IV(a), indicates that exposure to $\mathrm{HCl}$ gas converted aluminum in the oxide to the volatile compound, $\mathrm{Al}_{2} \mathrm{Cl}_{6}$. The following reaction is proposed:

$$
\mathrm{Al}_{2} \mathrm{O}_{3}+6 \mathrm{HCl} \longrightarrow \mathrm{Al}_{2} \mathrm{Cl}_{6}+3 \mathrm{H}_{2} \mathrm{O}
$$

This reaction is known to occur, and in fact was the basis for commercial production of the dimer $\mathrm{Al}_{2} \mathrm{Cl}_{B}$ in the past. The $\mathrm{HCl}$ gas then would react with the base metal as follows:

$$
\begin{aligned}
& \mathrm{Ti}+2 \mathrm{HCl} \longrightarrow \mathrm{TiCl}_{2}+2 \mathrm{H} \\
& 2 \mathrm{Al}+6 \mathrm{HCl} \longrightarrow \mathrm{Al}_{2} \mathrm{Cl}_{6}+6 \mathrm{H} \\
& \mathrm{V}+\mathrm{xHCl} \longrightarrow \mathrm{VCl}_{\mathrm{X}}:+\mathrm{xH}
\end{aligned}
$$

Absorption of the hydrogen generated by these reactions could readily cause embrittlement and subsequent delayed-failure.

It is important to note that reaction of only one atom of titanium and two atoms of aluminum with $\mathrm{HCl}$ yleld elght atoms of hydrogen. Therefore, a minute amount of general surface reaction in HCl gas could generate a considerable amount of hydrogen without producing much visible evidence of corrosion.

The pattern of cracking produced by $\mathrm{HCl}$ gas (F1gure 1 ) is difficult to rationalize on the basis of localized, stress-accelerated corrosion which should always occur in a direction nearly normal to the tensile stress. However, an abrupt mechanical rupture due partially to high internal stresses might produce such a pattern. This pattern is interpreted as evidence that fracture was due to hydrogen embrittlement.

The fracture surfaces of cracks produced at $650^{\circ} \mathrm{F}$ by exposure to $\mathrm{HCl}$ gas and to NaCl are compared in Figure 2. The surface of the fracture produced by $\mathrm{HCl}$ shows characteristic patterns of mechanical cleavage, whereas corrosion is evident in the NaCl cracks. The latter observation does not preclude the possibility that the corrosion occurred after the cracks had been formed by mechanlcal rupture of metal embrittled by corrosion-produced hydrogen.

Studies in progress using radiotracer ${ }^{3} \mathrm{H}$ (tritium) should clarify the role of hydrogen. Those studies are described in the following section. 


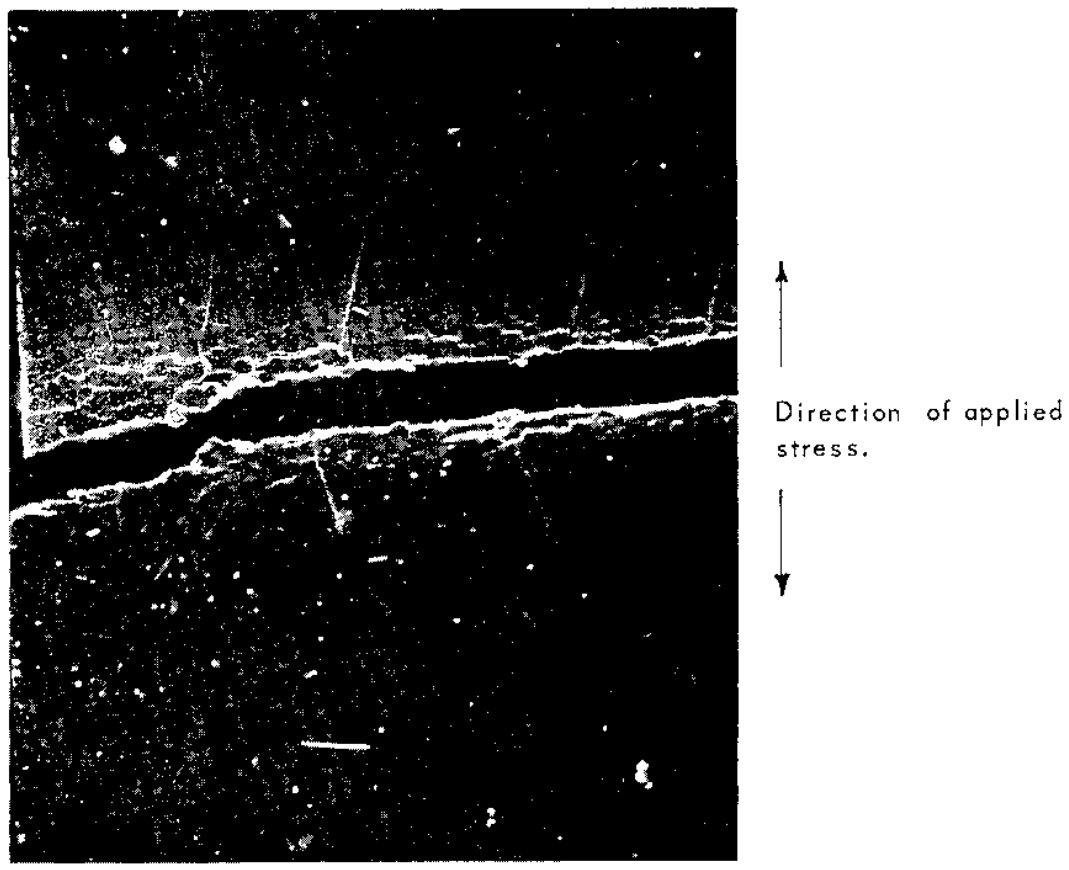

a. Dark field view showing main cracks and secondary cracks forming chevron pattern. (10X)

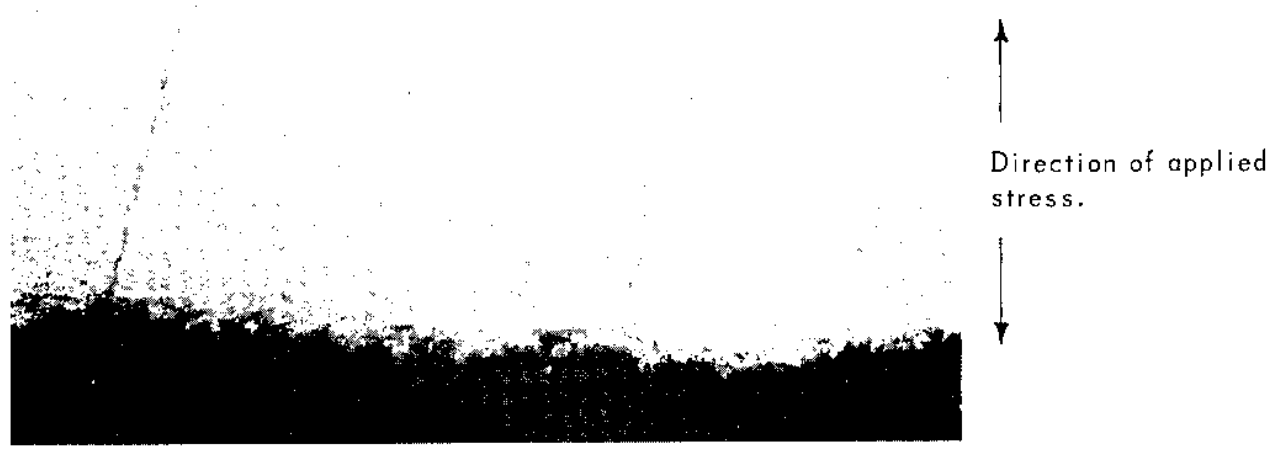

b. Bright field view showing more detail

of secondary cracking. (55X)

FIG. 1 TYPICAL CRACK PATTERN ON SURFACE OF STRESSED TI-8AI-IMO-IV

ALLOY EXPOSED IN ANHYDROUS HCI GAS AT $650^{\circ} \mathrm{F}$ FOR $6 \frac{1}{2} \mathrm{HR}$ 

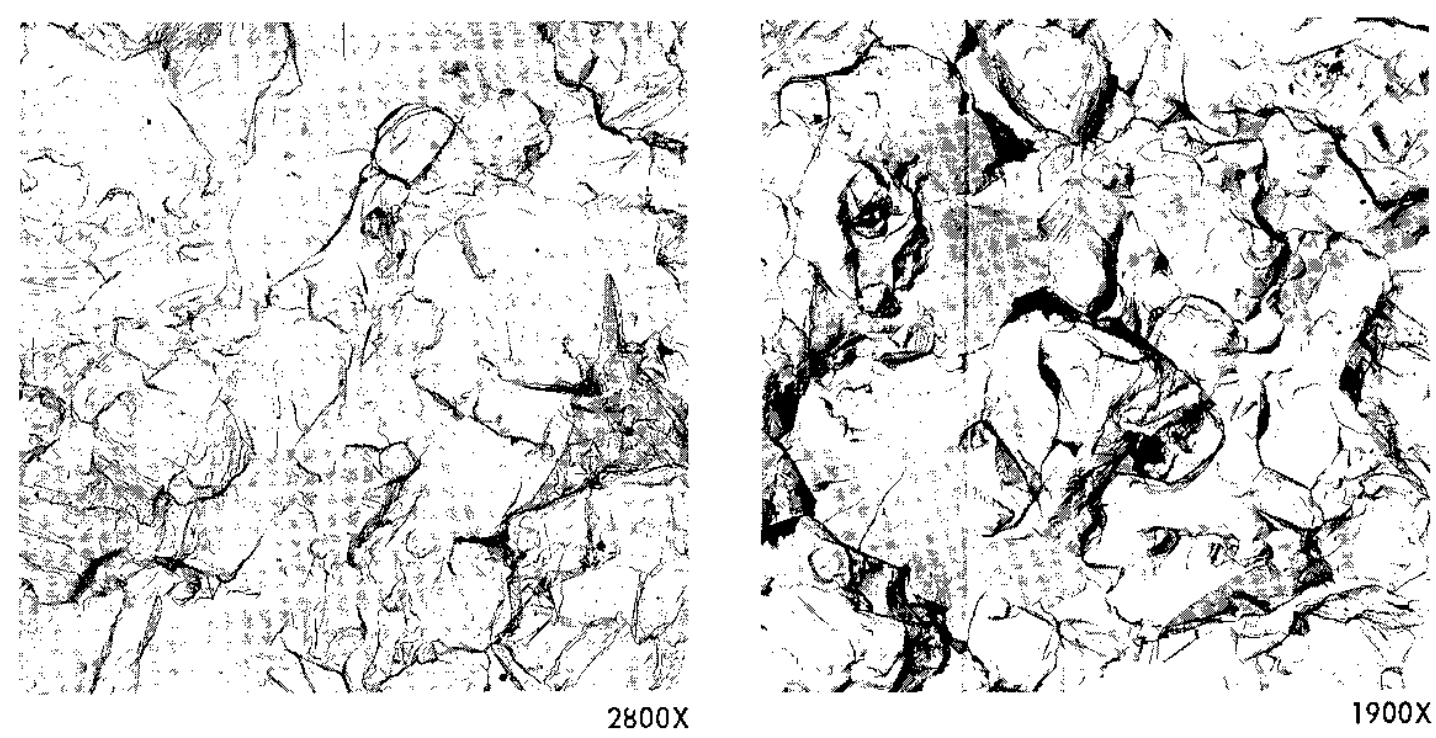

a. Cracks produced by $\mathrm{HCl}$ exposures.
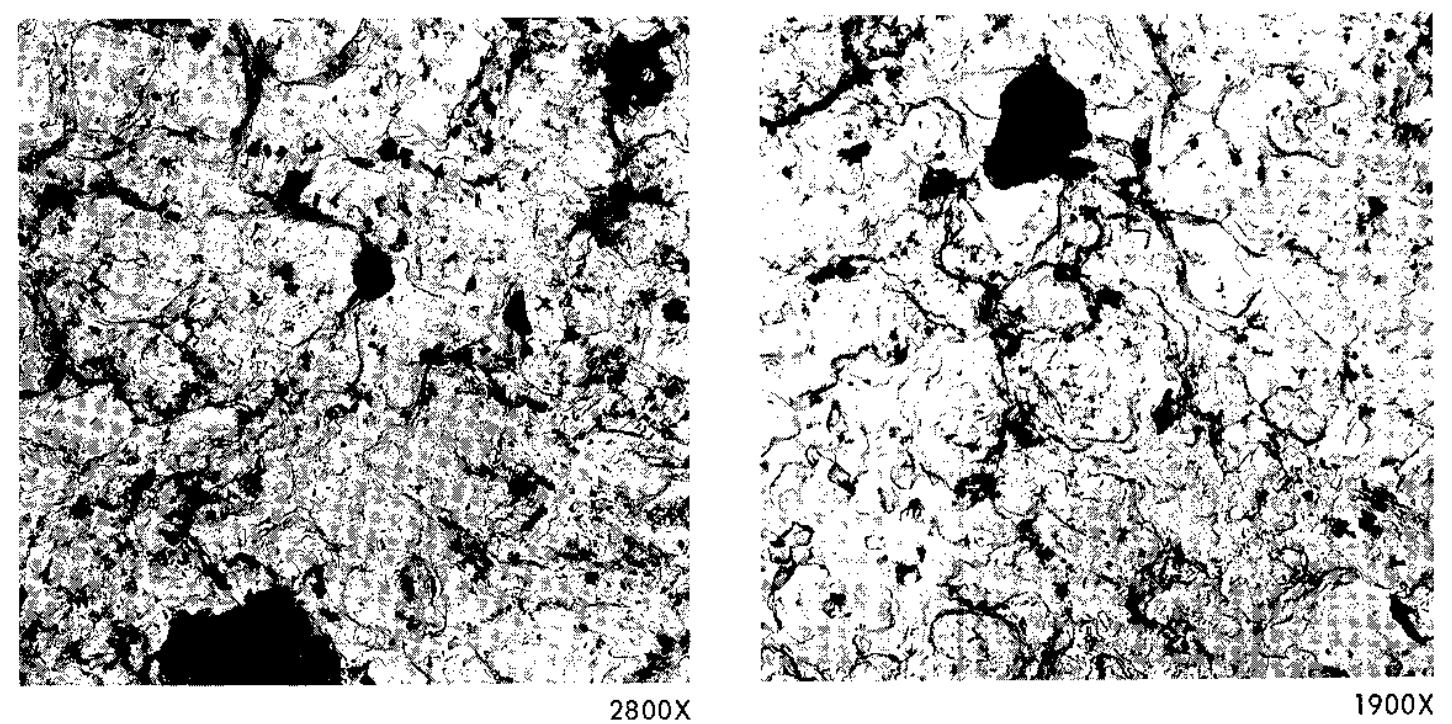

b. Cracks produced by $\mathrm{NaCl}$ exposures.

FIG. 2 FRACTOGRAPHIC COMPARISON OF CRACKS DEVELOPED IN Ti-8AI-IMO-IV ALLOY EXPOSED AT $650^{\circ} \mathrm{F}$ TO ANHYDROUS $\mathrm{HCl}$ AND TO $\mathrm{NaCl}$. The surface of the specimen cracked with $\mathrm{HCl}$ is clean and shows evidence of cleavage fracture, whereas extensive corrosion is apparent on the surfaces of the cracks induced by $\mathrm{NaCl}$. 
Role of Hydrogen in Hot-Salt Cracking

The deleterious effects of hydrogen on the mechanical properties of titanium alloys are well documented. Because of such effects and the presence of hydrogen-bearing compounds $\left(\mathrm{H}_{2} \mathrm{O}, \mathrm{HCl}, \mathrm{NaOH}\right.$, etc) in most, if not all, environments known to cause hot-salt cracking, the role of hydrogen in the cracking phenomenon could be of prime importance.

Previous SRL tests with $\mathrm{Na}^{36} \mathrm{Cl}$ and ${ }^{22} \mathrm{NaCl}$ showed that chloride was retained uniformly in the area initially wetted by the salt solution, but that sodium was retained only where salt crystals which formed during drying adhered to the sample surface. (3) Assuming that no metal corrosion occurs initially and that a charge balance is maintained in the surface film, the adsorption of $\mathrm{Cl}^{-}$must elther be accompanied by adsorption of $\mathrm{H}^{+}$, or some oxygen lons must be displaced from the film. Autoradiography of samples exposed to salt water contalining radiotracer ${ }^{3} \mathrm{H}$ showed that hydrogen in some form is adsorbed with the $\mathrm{Cl}^{-}$, and the tentative conclusion is that most of the adsorbed hydrogen is either molecular $\mathrm{HCl}$ or $\mathrm{H}^{+}$lons dispersed along with $\mathrm{Cl}^{-}$lons in the oxide f1Im. Some adsorbed molsture may also be present. These tests are described in detall below.

A large drop of tritlated water saturated with $\mathrm{NaCl}$ was placed on a stressed sample and dried by slowly heating to $250^{\circ} \mathrm{F}$. During this time the alr over the sample was monitored for tritium radioactivity, and a high count rate was obtained throughout the drying period. After the salt appeared to be dry, no airborne activity was detected. The temperature was then increased and maintained at $650^{\circ} \mathrm{F}$ for one week. After the exposure, the sample was photographed to show the salt deposit and the corrosion pattern (at low and high magnifications) after the salt was removed. Some cracks were visible at high magnification. Then the sample was coated with a thin flim of Kodak NTB-2 liquid emulsion. The emulsion was exposed and developed in situ, and the sample was photographed again at low and high magnifications to show distribution of the radiotracer ${ }^{3} \mathrm{H}$. The sequence at low magnification is shown in Figure 3 .

Careful comparison of Flgures $3 \mathrm{~b}$ and $\mathrm{c}$ reveals that hydrogen was retained fairly uniformly over the area initially wetted by the salt solution. The form of this hydrogen is assumed to be ionic on the basis that this satisfies the charge balance in the surface film. The validity of this assumption and the possibility that some water is also adsorbed is being investigated in continuing studies with radiotracer ${ }^{3} \mathrm{H}$. 


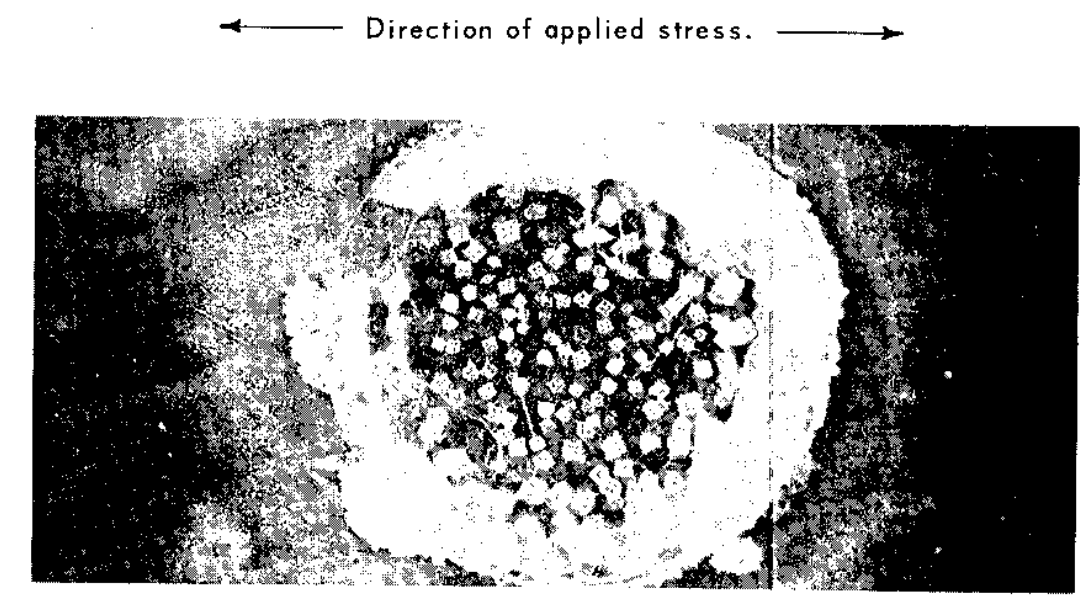

a. Before rinsing in $\mathrm{H}_{2} \mathrm{O}$.

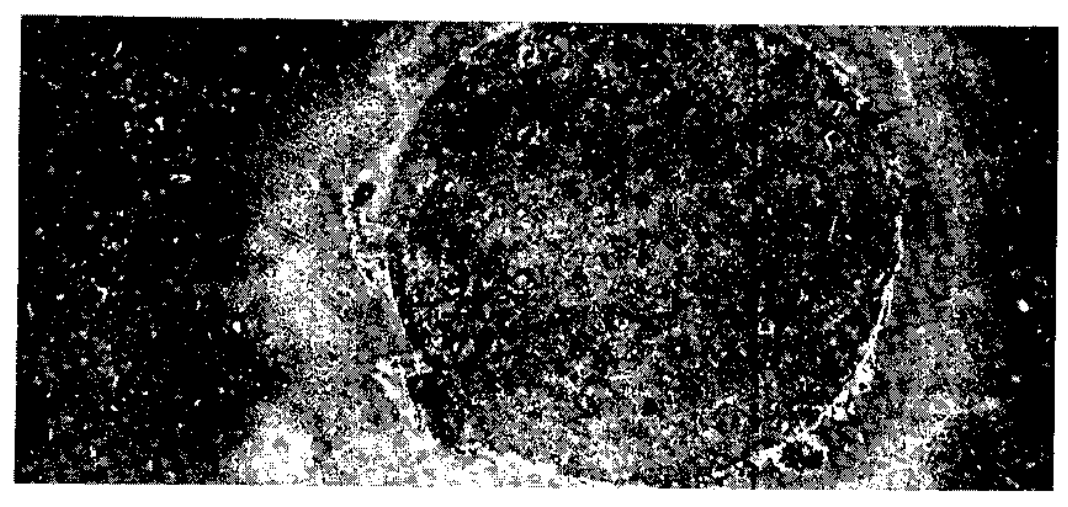

b. After $\mathrm{H}_{2} \mathrm{O}$ rinse, before autoradiography.

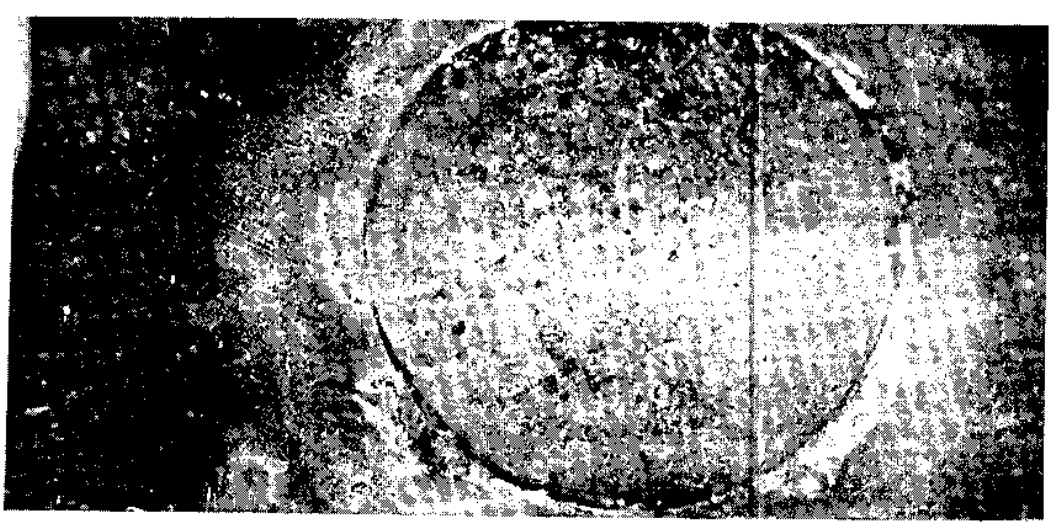

c. After autoradiography (film in situ).

FIG. 3 DISTRIBUTION OF ${ }^{3} \mathrm{H}$ ON SALT-CORRODED Ti-8AI-1MO-IV ALLOY (5X). Areas affected by the radiotracer ${ }^{3} \mathrm{H}$ appear lighter than adjacent areas of the film at this magnification (oblique lighting). 
The appearance of the sample at high magnification is shown in Figure 4. In areas with no evidence of salt attack, the radiotracer ${ }^{3} \mathrm{H}$ was retained fairly uniformly (Figures $4 a$ and $b$ ) as was the case with radiotracer ${ }^{36} \mathrm{Cl}$ reported previously. In areas of salt corrosion (Figures $4 \mathrm{c}$ and $\mathrm{d}$ ), the distribution of ${ }^{3} \mathrm{H}$ appeared nonuniform on a microscopic scale. Part of the apparent nonuniformity is believed to be due to variations of oxide film thickness. If the ${ }^{3} \mathrm{H}$ is concentrated at the oxide-metal interface, some beta radioactivity would be absorbed in areas of thicker oxide $(0.2 \mu)$ because the energy of the radiation is extremely low $(0.0181 \mathrm{Mev})$. Attempts to determine if hydrogen is concentrated in cracks have been unsuccessful to date.

Adsorption of hydrogen and chlorine ions on the surface of samples initlally wetted with salt water appears to be a key factor in promoting susceptibility to hot-salt cracking. Evidence supporting this was obtained by comparing the cracking tendency of samples with and without the adsorbed ions. In one test, $\mathrm{NaCl}$ crystals that had been predried for 3 days at $650^{\circ} \mathrm{F}$ were placed on a polished and stressed sample that had never been wetted with salt water and therefore had no hydrogen or chlorlde ions adsorbed on the surface. This sample was exposed for one week in stagnant air at $650^{\circ} \mathrm{F}$, and no cracking occurred.

In the comparison test, similarly preheated $\mathrm{NaCl}$ crystals were placed on a sample that had been wetted with saturated NaCl solution for 15 minutes at room temperature and then blotted dry with tissue paper. Numerous cracks were visible after exposure for one week at $650^{\circ} \mathrm{F}$ in stagnant air. A sample wetted with saturated $\mathrm{NaCl}$ solution and blotted dry at room temperature, but with no $\mathrm{NaCl}$ crystals added, did not crack during exposure for two weeks at $650^{\circ} \mathrm{F}$. These results show that the adsorbed ions and the presence of salt crystals are both required for cracking to occur.

Role of $\mathrm{NaOH}$ and Preferential Attack of $\mathrm{Al}$ in Cracking

The hypothesis that $\mathrm{HCl}$ (or $\mathrm{H}^{+}$and $\mathrm{Cl}^{-}$) is adsorbed on the surface during drying of the salt deposit requires that an equivalent amount of $\mathrm{NaOH}$ be formed in the salt, because the salt solution, as applied initially, is essentially neutral. Therefore, the possible role of $\mathrm{NaOH}$ in hot-salt cracking is being investigated.

Previous evidence ${ }^{(3)}$ that radiotracer ${ }^{22} \mathrm{Na}$ was retained only at spots where $\mathrm{NaCl}$ adhered indicates that any $\mathrm{NaOH}$ formed would be at these same spots. Corrosion at spots of intimate contact could be due to $\mathrm{NaOH}$ converting the oxide to nonprotective hydroxides which would allow easy anodic oxidation of the metal at these sites. 


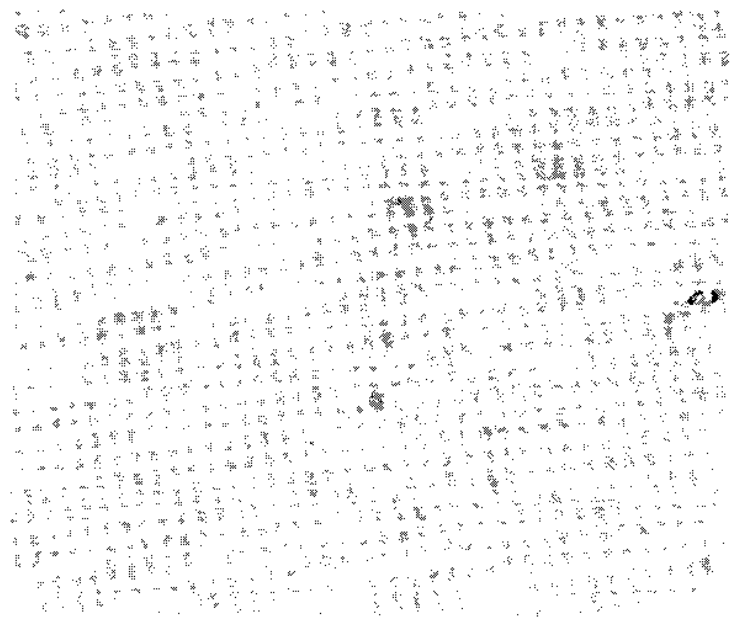

a. Before autoradiography.

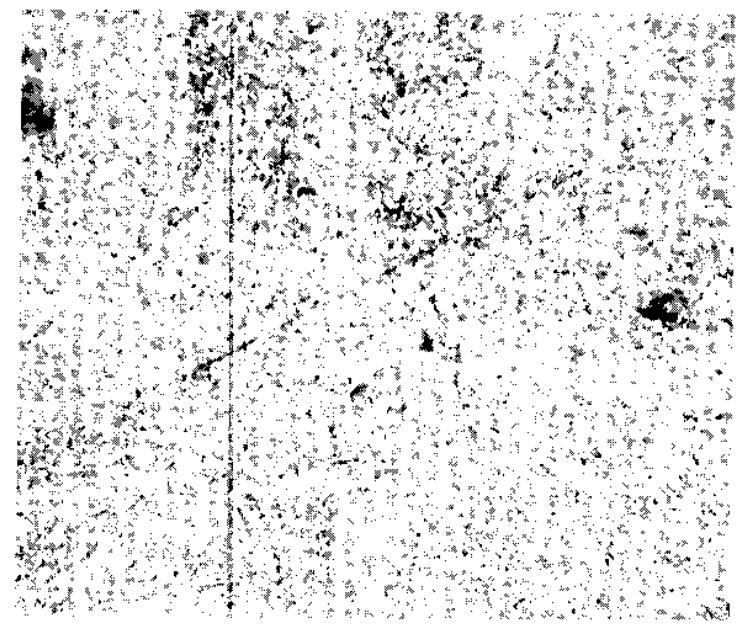

b. After autoradiography.

Area where no salt corrosion occurred but where the sample was wetted by salt solution prior to exposure.

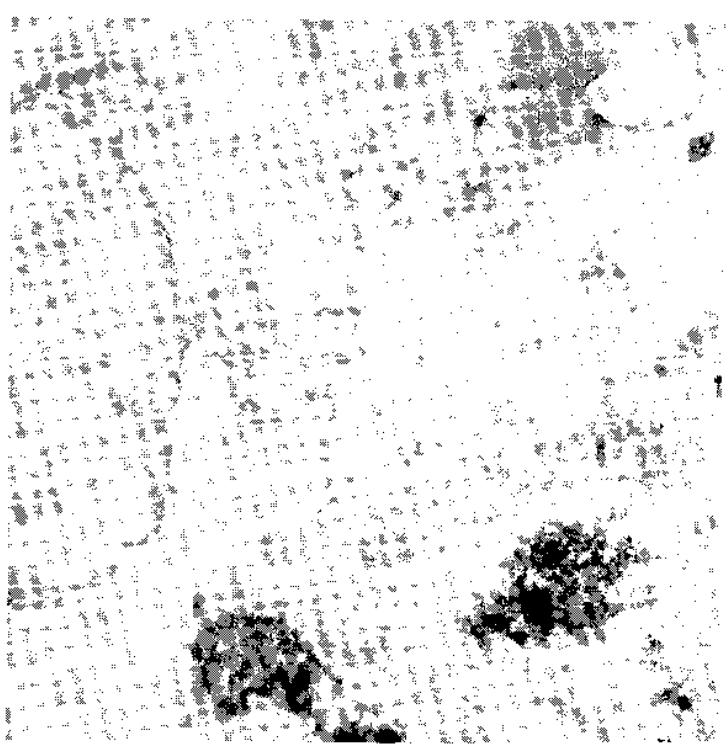

c. Before autoradiography.

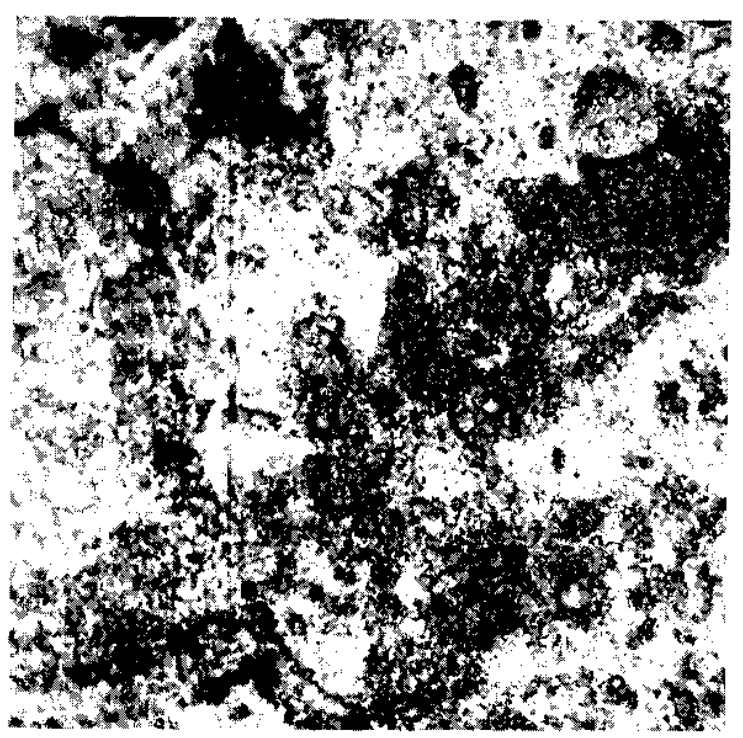

d. After autoradiography.

Area where salt corrosion occurred during exposure.

FIG. 4 DISTRIBUTION OF ${ }^{3} H$ ON SALT-CORRODED Ti-8AI-1MO-IV ALLOY (500X). (High magnification photographs of sample shown in Figure 3 )

Areas affected by the radiotracer ${ }^{3} \mathrm{H}$ appear as black specks at this magnification (bright field illumination). 
Results of experiments to date show that $\mathrm{NaOH}$ in the absence of salt does cause pitting corrosion but does not cause cracking. The results also show that alloying elements in the metal are preferentially attacked by $\mathrm{NaOH}$. Furthermore, samples exposed to $\mathrm{NaOH}$ at $650^{\circ} \mathrm{F}$, then washed and re-exposed to $\mathrm{NaCl}$ did not crack. These observations indicate that preferentlal attack of alloy elements during exposure to chlorides is a key factor in hot-salt cracking. Previous work ${ }^{(3)}$ showed that corrosion products on samples cracked by $\mathrm{NaCl}$ were rich in aluminum, and one effect of pre-exposure to $\mathrm{NaOH}$ was to deplete aluminum from the surface. Detalls are given below.

Two stressed samples (four-point loaded) were coated with $\mathrm{NaOH}$ and heated at $650^{\circ} \mathrm{F}$ for 10 days. After this exposure, the samples were washed to remove $\mathrm{NaOH}$ and examined. Some corrosion had occurred, but no cracks were detected. A deposit of $\mathrm{NaCl}$ was then applied to these samples and they were re-exposed at $650^{\circ} \mathrm{F}$ for 7 days. Subsequent examination revealed no cracking except for one tiny crack on one sample at an edge that had not been covered by $\mathrm{NaOH}$ initially. The nature of the corrosion produced by the combined $\mathrm{NaOH}-\mathrm{NaCl}$ exposure is shown in Figure 5 .

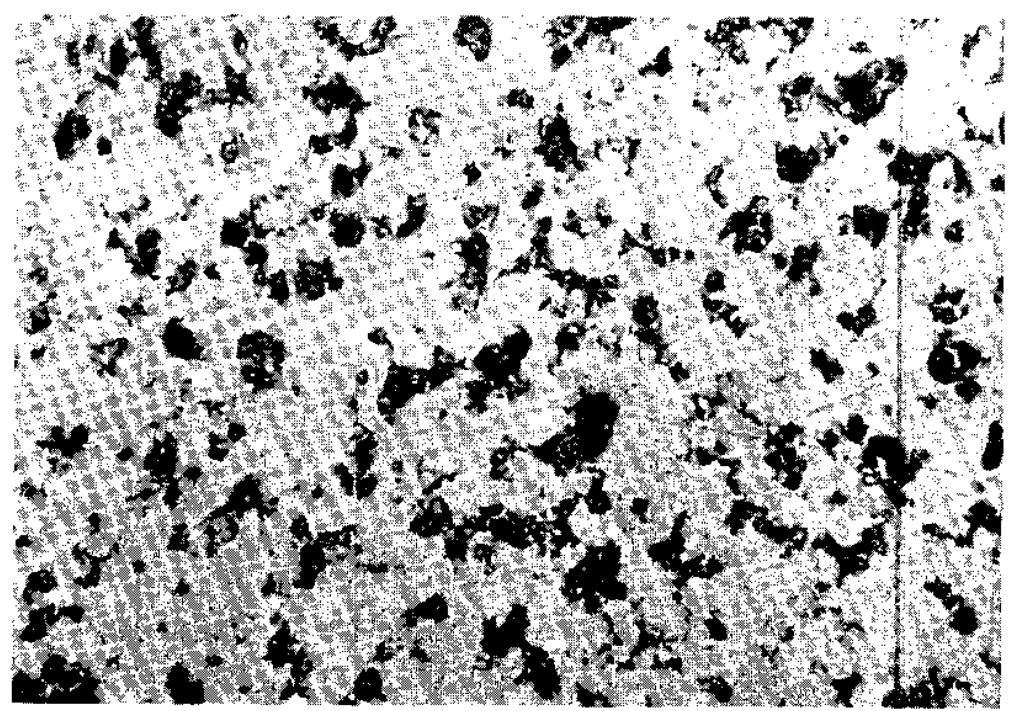

FIG. 5 MICROSCOPIC APPEARANCE OF SURFACE OF STRESSED TI-8AI-IMO-IV ALLOY EXPOSED TO NaOH AT $650^{\circ} \mathrm{F}$ FOR 10 DAYS, THEN EXPOSED TO NaCl AT $650^{\circ} \mathrm{F}$ FOR 7 DAYS. No cracking occurred during these exposures. (500X) 
Analyses of water used to wash corroded samples showed that $\mathrm{NaOH}$ exposures caused preferential attack of aluminum. The following experiments were performed:

I A stressed sample was covered with $\mathrm{NaOH}$ powder and held 12 days at $650^{\circ} \mathrm{F}$ (above the melting point of $\mathrm{NaOH}$ ). The $\mathrm{NaOH}$ was then rinsed off with $10 \mathrm{cc}$ of deionized water.

II A stressed sample was exposed to $\mathrm{NaOH}$ at $650^{\circ} \mathrm{F}$ for 10 days. The $\mathrm{NaOH}$ was subsequently cleaned of $\mathrm{with}$ boiling distilied water, and the sample was then exposed to $\mathrm{NaCl}$ at $650^{\circ} \mathrm{F}$ for one week. Loose salt was tapped off and the adhering salt was rinsed off with $10 \mathrm{cc}$ of distilled water.

The rinsings were evaporated and the residues were spectrochemically analyzed for Ti, Al, Mo, and V. Results expressed as parts per million parts of sodium were as follows:

\begin{tabular}{|c|c|c|c|c|}
\hline & Concentrati & n, parts & per $10^{6}$ & arts sodium \\
\hline Experiment & $\mathrm{Ti}$ & $A 1$ & Mo & $\mathrm{V}$ \\
\hline$I$ & $\begin{array}{c}40,000 \\
(4 \%)\end{array}$ & $\begin{array}{l}25,000 \\
(2.5 \%)\end{array}$ & $\begin{array}{c}4000 \\
(0.4 \%)\end{array}$ & $\begin{array}{c}10,000 \\
(1 \%)\end{array}$ \\
\hline II & $\gg 1000$ & 30 & 100 & 500 \\
\hline
\end{tabular}

In Experiment I the alloying elements in the metal, especlally aluminum and vanadium, were preferentlally attacked. In Experiment II, the products of $\mathrm{NaCl}$ attack on a sample previously exposed to $\mathrm{NaOH}$ contained very little aluminum, apparently because the aluminum was preferentially removed by the $\mathrm{NaOH}$ exposure.

The fact that pure titanium is not susceptible to hot-salt cracking indicates that preferential attack of alloying elements must be involved. Therefore, reactions proposed in the literature to represent cracking by attack of titanium alone by chlorine or chloride cannot be accepted as a complete explanation.

If hot-salt cracking occurs as a result of localized, stressaccelerated corrosion, a low-melting compound rich in aluminum and/or vanadium may be responstble for crack propagation.

An alternate possibility is that corrosion produces hydrogen which subsequently embrittles the alloy. It was shown earlier that corrosion of aluminum could produce more hydrogen than corrosion of titanium and therefore preferential corrosion of aluminum could be necessary in order 
to produce enough hydrogen to cause hydrogen embrittlement of the alloy. Further work is in progress to resolve the role of the preferential attack of alloying elements in the cracking phenomenon.

\section{Effects of Corrosion, Stress, and Temperature on Cracking}

Corrosion by $\mathrm{NaCl}$ deposits on unstressed samples was investigated to determine if the nature of the attack changed with temperature in any way that could be related to the apparent threshold temperature for cracking that has been reported to be about $550^{\circ} \mathrm{F} .{ }^{(5)}$ Unstressed, metallographically polished strips of duplex-annealed (heat D-5657) Ti-8AI-IMO-IV alloy were exposed in air for $1,2,3,5$, and 24 hours at $200,300,400$, and $650^{\circ} \mathrm{F}$, then metallographically examined to determine the effects of exposure.

At all temperatures corrosion started within one hour, and both increasing exposure time and temperature increased the extent of corrosion. There was no variation in the appearance of the attack with temperature, suggesting that there was little or no difference in the corrosion reactions.

A corrosion product (Figure 6) was often extracted from the reaction site on the cellulose acetate-carbon replicas used in electron metallography of the samples. This phase was examined by selected area electron diffraction and tentatively indexed as a body-centered cubic structure with a lattice parameter of approximately $5.15 \AA$. The composition of the phase has not yet been determined. The "feathery" appearance of the extracted phase was quite pronounced in regions having only slight corrosion but was not nearly as apparent and sometimes lacking, in regions where extensive corrosion had occurred. The relationship of the extracted phase to hot-salt cracking has not yet been established.

FIG. 6 UNIDENTIFIED PHASE EXTRACTED FROM Ti.8Al.1MO-IV ALLOY AFTER ATTACK BY NaCl. Note "feathery" appearance of some of the particles. Tentatively indexed as body-centered cubic $\left(a_{0} \sim 5.15 \AA\right)$.

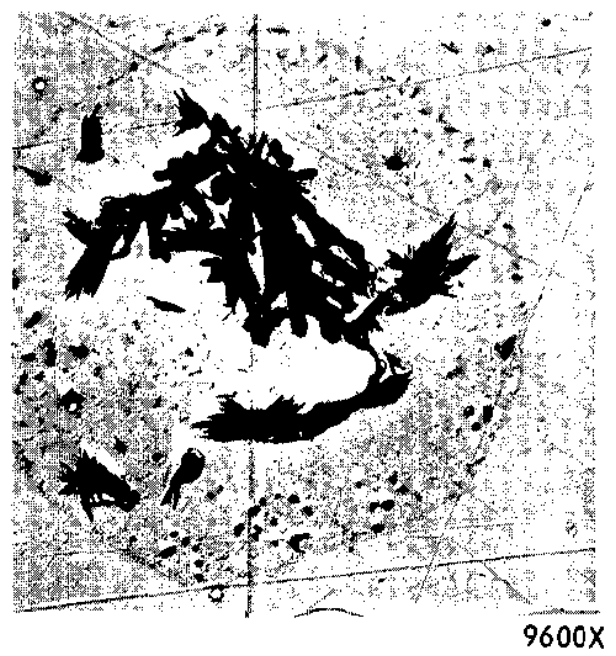


The same phase was extracted from the fracture faces of samples that were cracked by exposure at $650^{\circ} \mathrm{F}$ to $\mathrm{NaCl}$ and to $\mathrm{HCl}$ gas. The amount present was much greater on samples cracked by $\mathrm{NaCl}$; only trace quantities of the phase were found on HCl fracture. This result indicates that this phase was probably not involved in $\mathrm{HCl}$ cracking and was produced after the cracks had formed. Efforts are continuing to identify the body-centered cubic phase and determine if it is involved in cracking by $\mathrm{NaCl}$. If so, one possible explanation for the apparent threshold temperature for cracking is that the melting point of the body-centered cubic phase corresponds to the threshold temperature.

Cyclic Tests

Tests on the TI-8AI-IMO-IV alloy by the Boeing Company showed that no cracks were produced in stressed samples after over 3000 hours of alternate immersion in a room temperature $3 \frac{1}{2} \% \mathrm{NaCl}$ solution and exposure at $550^{\circ} \mathrm{F}$. The unit cycle time was 3 hours including 10 minutes immersion in the solution. In contrast, severe cracking occurred after exposure for similar times at constant temperature. ( $\left.{ }^{\prime}\right)$ These results indicated that ( 1 ) an incubation period that is longer than the 3-hour cycle time is required for cracking to begin and (2) that attack at a specific location during one cycle is not continued at that point in subsequent cycles. No direct evidence was available in the Boeing work to confirm this hypothesis, and therefore, an experiment was performed at SRL to test it.

A stressed sample of heat D-5657 was wet ground through 600 grit paper then coated with a $\mathrm{NaCl}_{-} \mathrm{H}_{2} \mathrm{O}$ solution and exposed for 24 hours at $650^{\circ} \mathrm{F}$. The salt was then rinsed from the sample and the surface was examined metallographically. Regions of corrosion were found throughout the sample and small cracks were observed (Figure $7 a$ ). The sample was then recoated with a $\mathrm{NaCl}-\mathrm{H}_{2} \mathrm{O}$ solution and exposed at $650^{\circ} \mathrm{F}$ for an additional 48 hours before rinsing and metallographic examination. The cracks that were observed after the initial exposure had not enlarged, but new cracks had formed in some areas where additional corrosion had occurred (Figure 7b). A third salt coating plus 100 hours additional exposure caused no increase in the length of cracks shown in Figure 7 , but, again, new cracks developed in other regions of the sample. These results confirm the indications of the Boeing tests that attack does not accumulate at specific locations in sequential exposures, and furthermore show that cracks formed during one exposure do not propagate during subsequent exposures. These observations, coupled with the Boeing results, are highly favorable with regard to SST operation because they suggest that under operating conditions the hot-salt cracking problem should be minimal. 


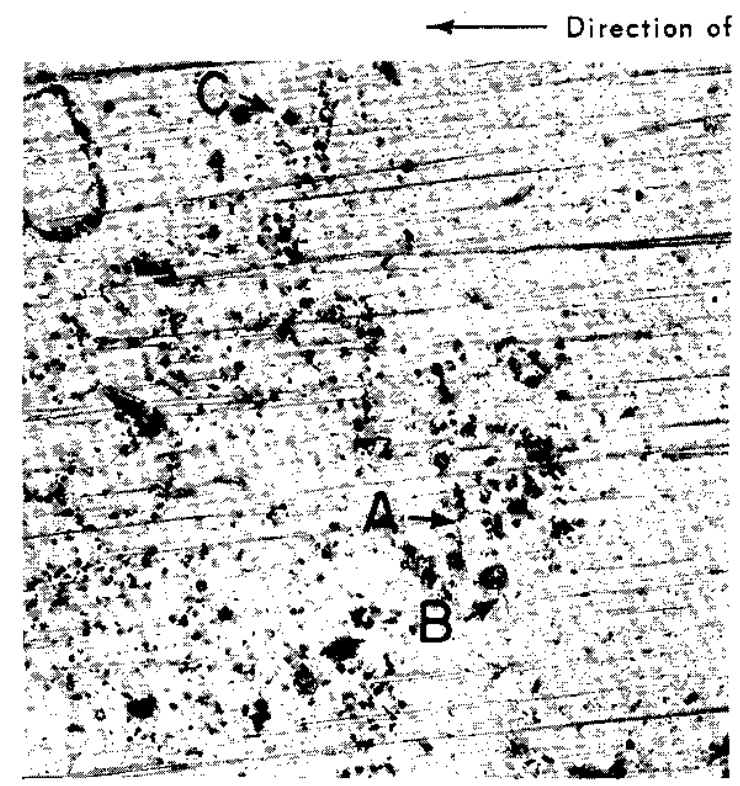

a. After 24 hours at $650^{\circ} \mathrm{F}$.

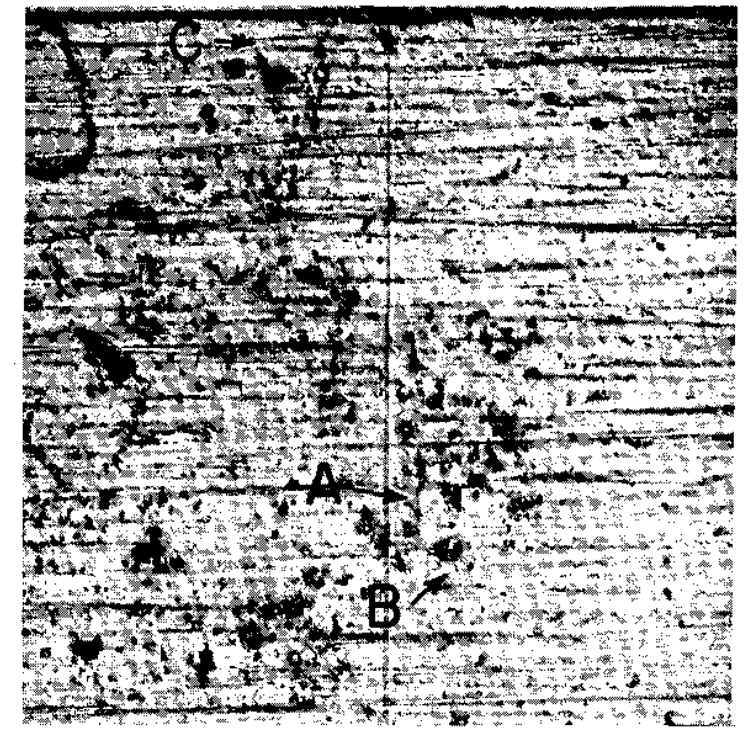

b. Same area as in (a) after a second cycle of 48 hours at $650^{\circ} \mathrm{F}$.

FIG. 7 EFFECT OF SUCCESSIVE $\mathrm{NaCl}$ EXPOSURES ON NUCLEATION AND PROPAGATION OF HOT-SALT CRACKS. Note that cracks $A$ and $B$ did not propagate during additional exposure and that a new crock formed at $C$. (150X)

\section{Effect of Heat Treatment on Cracking}

Last quarter, results were reported(3) which showed that variations in cooling rates from $1450^{\circ} \mathrm{F}$ affected the susceptibility of the Ti-8Al-IMo-IV alloy to hot-salt cracking. At that time the differences in cracking susceptibility were believed to be caused by segregation of some alloy constituent during slow cooling, because no differences in structure could be detected by examination of the materials by optical and electron microscopy; however, X-ray studies of the effect of slow cooling had not been made. During the past quarter X-ray studies of the effects of quenching and slow cooling on the structure of the alloy were completed and no evidence of structural change or ordering was observed.

\section{Effect of Oxygen}

It was postulated previously that cathodic reduction of hydrogen lons or oxygen (or both) is required to sustain hot-salt attack on titanium alloys. Fxperiments described below were performed to determine the importance of oxygen in hot-salt cracking. 
Self-stressed specimens coated with $\mathrm{NaCl}$ were exposed at $650^{\circ} \mathrm{F}$ for 2 weeks in an argon atmosphere and in air at a pressure of 1 to $2 \mathrm{~mm}$ of $\mathrm{Hg}$. The specimen exposed to argon was placed in a glass tube, and the tube was evacuated and flushed once to remove air before final evacuation, filling with argon, and sealing. Argon pressure was one atmosphere at $650^{\circ} \mathrm{F}$. Profuse cracking occurred in both samples, indicating that very little air is required to sustain the stress corrosion reaction.

This result together with the fact that some form of hydrogen was shown to be adsorbed with chlorides in salt-coated areas indicates that the primary cathodic reaction may be hydrogen ion reduction.

\section{Effect of Various Halogen lons on Cracking}

Results reported last quarter ${ }^{(3)}$ indicated that hot-salt cracking occurred when stressed specimens were exposed at $650^{\circ} \mathrm{F}$ in three-pointloaded jigs while exposed to NaI and NaBr. These results were confirmed using four-point-loading jigs and with only one type salt exposed in a furnace at a time to avoid possible decrepitation or gas-transfer effects. Identical samples exposed to NaF for 2 weeks did not crack; however, a uniform distribution of tiny pits was observed throughout the sample surface (Figure 8).

The fact that $\mathrm{NaF}$ did not cause cracking may be related to the stability of fluoride compounds and its nonhydrolyzing character; however, further work is required to establish the effect of the halogen ion.

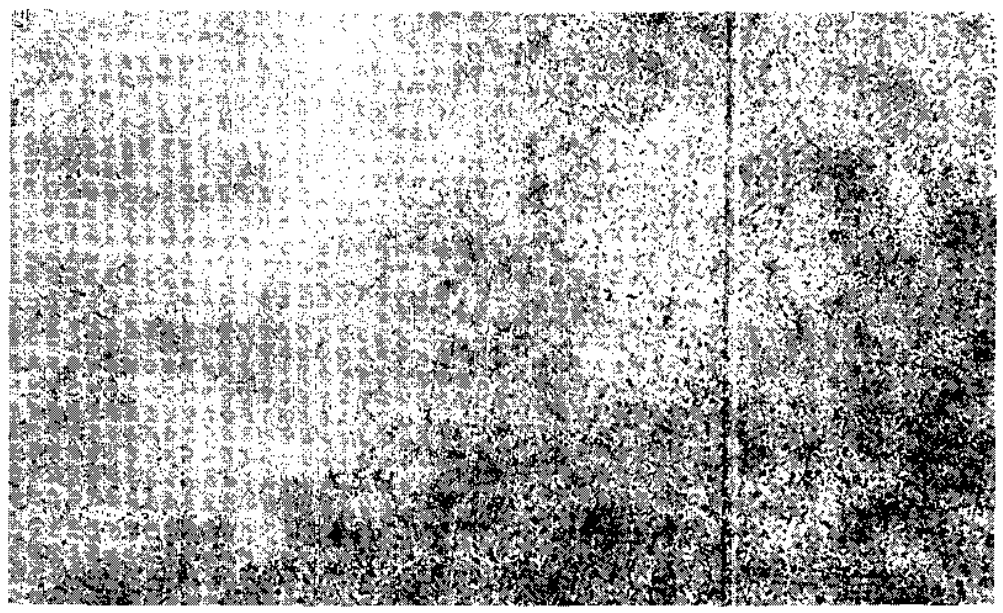

FIG. 8 APPEARANCE OF STRESSED Ti-8AI-1Mo-IV ALLOY EXPOSED TO NaF FOR 14 DAYS AT $650^{\circ} \mathrm{F}$. No cracking occurred during exposure. (250X) 


\section{REFERENCES}

1. S. P. Rideout, M. R. Louthan, Jr., and C. L. Selby. Stress CorroSion Cracking of Titanium Alloys, Progress Report - April I June 30, 1964. USAEC Report DP(NASA)-917, E. I. du Pont de Nemours \& Co., Savannah River Laboratory, Aiken, S. C. (1964).

2. S. P. Rideout, M. R. Louthan, Jr., and C. L. Selby. Stress Corrosion Cracking of Titanium Alloys, Progress Report - July 1 September 30, 1964. USAEC Report DP(NASA)-94I, E. I. du Pont de Nemours \& Co., Savannah River Laboratory, Aiken, S. C. (1964).

3. S. P. Rideout, M. R. Louthan, Jr., and C. L. Selby. Stress Corrosion Cracking of Titanium Alloys, Progress Report - October I December 31, 1964. USAEC Report DP(NASA)-961, E. I. du Pont de Nemours \& Co., Savannah River Laboratory, Aiken, S. C. (1965).

4. D. N. Braski and G. J. Heimerl. The Relative Susceptibility of Four Commercial Titanium Alloys to Salt Stress Corrosion at $55^{\circ} \mathrm{F}$. NASA TN D-2011, Langley Research Center, Langley Station, Hampton, Virginia (1963).

5. W. K. Boyd and F. W. Fink. The Phenomenon of Hot-Salt StressCorrosion Cracking of Titanium Alloys. NASA CR-117, Battelle Memorial Institute, Columbus, Ohio (1964).

6. "A Progress Report on the Applied Stress Corrosion Studies of Titanium Alloys at the Airplane Division of the Boeing Company, Renton, Washington." Paper presented at the Twelfth Meeting of NASA Special Committee of Materials Research for Supersonic Transports, NASA Headquarters, Washington, D. C., February 1965. 